\title{
Can spring cattle grazing among young bitterbrush stimulate shrub growth?
}

\author{
DAVE GANSKOPP, TONY SVEJCAR, FRED TAYLOR, AND JERRY FARSTVEDT
}

Authors are Range Scientists, USDA-ARS, Eastern Ore. Agr. Res. Ctr., 67826-A Hwy. 205, Burns, Ore. 97720; Wildlife Biologist, USDI-BLM, 28910 Hwy. 20 W., Hines, Ore. 97738; Habitat Biologist (retired), Oregon Dept. Fish and Wildlife, Box 8, Hines, Ore. 97738.

Abstract

Due to its palatability and forage quality, antelope bitterbrush (Purshia tridentata Pursh DC) is a desirable shrub across western US rangelands. Because little information is available regarding grazing management of young bitterbrush, a study was undertaken to explore stocking pressure thresholds and quantify effects of light and heavy spring cattle grazing on shrub growth. Rates of browsing and trampling and forage availability were monitored over 3 years in southeast Oregon. Across years, 29\% of bitterbrush endured trampling in light-grazing treatments, and $55 \%$ experienced trampling under heavy grazing. Linear models relating time and cattle density successfully explained $\left(\mathbf{r}^{2}\right.$ $=0.84-0.86$ ) probabilities of bitterbrush being trampled. Forage utilization averaged $32 \%$ and $59 \%$ in lightly and heavily grazed units, and 14 and $62 \%$ of bitterbrush were browsed in lightly and heavily-grazed pastures, respectively. Cattle began browsing when herbaceous standing crop declined to $100-150 \mathrm{~kg} \mathrm{ha}^{-1}$. Browsing in heavily-grazed pastures reduced diameters of bitterbrush by 4.5 to $9.5 \mathrm{~cm}$ in 1998 and 1999, but shrub height was unaffected. Lightly-grazed stands exhibited a $50 \%$ greater increase in bitterbrush diameter, $\mathbf{3 0} \%$ greater height increment, and $8 \%$ longer twigs than shrubs in ungrazed pastures. At the end of the 1997 and 1998 growing seasons, bitterbrush in heavilygrazed pastures were $11 \mathrm{~cm}$ greater in diameter than ungrazed controls and equal to shrubs in lightly-grazed pastures. To stimulate bitterbrush growth, young stands can be lightly-grazed (30 to $40 \%$ utilization of herbaceous forage) by cattle when bitterbrush is flowering and accompanying grasses are in vegetative to late-boot stages of phenology.

Key Words: Purshia tridentata, livestock, big game, winter range, wildlife, habitat, browse

Antelope bitterbrush (Purshia tridentata Pursh DC) is an important shrub for mule deer (Odocoileus hemionus hemionus), pronghorn (Antilocarpa americana), and livestock on western North America rangelands (Kufeld et al. 1973, Vavra and Sneva 1978, Neal 1981, Urness 1981, Kinuthia et al. 1992). With a sustained crude protein content above $8.0 \%$ (Hickman 1975 and Kituku et al. 1992), bitterbrush can substantially enhance lateseason diet quality of ruminants when nutritive value of herbaceous forages has declined to sub-maintenance levels (Ganskopp and Bohnert 2001). Bitterbrush occurs among numerous vegeta-

Eastern Oregon Agricultural Research Center is jointly operated by the Oregon Agr. Exp. Sta. of Oregon State Univ. and the USDA-Agricultural Research Service.

Manuscript accepted 1 Jụl. 03

\section{Resumen}

Debido a su gustocidad y calidad de forraje el "Antelope bitterbrush" (Purshia tridentata Pursh DC) es un arbusto deseable en los pastizales del oeste de U.S.A. Debido a que hay poca información disponible respecto al manejo del apacentamiento de plantas jóvenes de "Bitterbrush", se condujo un estudio para explorar los umbrales de la presión de apacentamiento y cuantificar los efectos del apacentamiento ligero y fuerte de ganado en primavera sobre el crecimiento del arbusto. Durante 3 años en el sudeste de Oregon se monitorearon las tasas de ramoneo y pisoteo y la disponibilidad de forraje. A través de los años, 29\% del "Bitterbrush" toleró el pisoteo en los tratamientos de apacentamiento ligero y en los tratamientos de apacentamiento fuerte 55\% del "Bitterbrush" sufrió el pisoteo. Modelos lineales relacionando tiempo y densidad de ganado explicaron exitosamente $\left(r^{2}=0.84-0.86\right)$ las probabilidades del "Bitterbrush" de ser pisoteado. La utilización del forraje promedio $32 \%$ y $59 \%$ en las unidades apacentadas ligera y fuertemente y 14 y $62 \%$ del "Bitterbrush" fue ramoneado en los potreros apacentados ligera y fuertemente respectivamente. El ganado inicio el ramoneo cuando la biomasa de las herbáceas diminuyó a 100-150 $\mathrm{kg} \mathrm{ha}^{-1}$. El ramoneo en los potreros con apacentamiento fuerte redujo los diámetros del "Bitterbrush" de 4.5 a 9.5 cm en 1998 y 1999, pero la altura del arbusto no fue afectada. Las poblaciones con apacentamiento ligero mostraron un incremento del $50 \%$ en el diámetro del "Bitterbrush", $30 \%$ más en la altura y las ramas fueron $8 \%$ más largas que las de los arbustos en los potreros sin apacentamiento. Al final de las estaciones de crecimiento de 1997 y 1998 el "Bitterbrush" de los potreros apacentados fuertemente fueron $11 \mathrm{~cm}$ más grandes en diámetro que los arbustos de los potreros control sin apacentamiento e igual a los arbustos de los potreros ligeramente apacentados. Para estimular el crecimiento del "Bitterbrush" las poblaciones jóvenes pueden ser ligeramente apacentadas (30 a $\mathbf{4 0 \%}$ de utilización del forraje herbáceo) por el ganado cuando el "Bitterbrush" esta en floración y los zacates acompañantes están en las etapas fonológicas de crecimiento vegetativo a fines de embuche.

tion types across approximately 140 million hectares (Hormay 1943) from British Columbia to California and east into Montana and New Mexíco (Cronquist et al. 1997).

Senescence, wildfires, a history of excessive herbivory, and low recruitment have, however, decreased bitterbrush abundance across much of its range (Billings 1952, Tueller and Tower 1979, Winward and Alderfer-Findley 1983, Ayers et al. 1999, Clements and Young 2001), and restoration efforts have frequently met with limited success (Hubbard 1964, Kituku et al. 1995). 
Hubbard (1957) and Dealy (1970) showed that competing vegetation can substantially reduce establishment and subsequent stature of bitterbrush seedlings, and plants must reach an age of 60 to 75 years before maximum annual yield is realized (McConnel and Smith 1977). Burning typically results in greater mortality of bitterbrush than does clipping or rotobeating (Mueggler and Blaisdell 1958, Clark et al. 1982), and heavy browsing may also reduce plant longevity (McConnel and Smith 1977). While young transplants appear to benefit from grazing protection (Dealy 1970, Ferguson 1968), established bitterbrush generally responds well to defoliation, and grazed plants produce more and longer twigs than ungrazed controls (Tueller and Tower 1979, Billbrough and Richards 1993, Kituku et al. 1994). Ganskopp et al. (1999) found that cattle only browsed bitterbrush lightly before competing grasses entered anthesis, and that shrubs in pastures lightly-grazed by cattle early in the growing season were larger in stature than cohorts in ungrazed controls. Spring mowing of competing vegetation also stimulates twig growth (Kituku et al. 1994). Accelerated twig growth may not occur on less productive sites (Kituku et al. 1994), and in some years annual production of twigs may also be affected by extremely low temperatures (Jensen and Urness 1979) and/or fluctuations in annual precipitation (Garrison 1953, Kindschy 1982).

Most bitterbrush research has focused on well-established stands or reclamation efforts, and there is little data regarding grazing management of young stands. Given that light, early season cattle grazing stimulated growth of 3 to 5-year-old bitterbrush (Ganskopp et al. 1999), a study was designed to evaluate bitterbrush responses to even heavier grazing applications restricted solely to the early growing season. The objectives of this research were: 1) to determine the effects of light and heavy early season cattle grazing on the subsequent stature and twig growth of 6-9 year old bitterbrush and 2) explore relationships among indices of forage availability and levels of browsing on shrubs to determine if stocking pressure thresholds for management of young bitterbrush stands could be established. These were accomplished by monitoring rates of shrub use, trampling damage, forage availability, and stature of young bitterbrush in lightly, heavily, and ungrazed pastures.

\section{Methods}

\section{Study site history and description}

In 1990, wildfire charred about 30,000 ha of Bureau of Land Management (BLM), United States Forest Service, and deeded property north and west of Burns, Ore. Much of the area consisted of pineforest/sagebrush-steppe-transition range which had historically been grazed by cattle and was important winter range for mule deer and elk (Cervus elaphus nelsoni). Revegetation efforts began immediately, and BLM properties were seeded with 'Secar' Snake River wheatgrass (Elymus lanceolatus (Scribner \& J.G. Smith) Gould) at $9 \mathrm{~kg} \mathrm{ha}$, and in areas where it had previously existed, antelope bitterbrush was included at a rate of $2.2 \mathrm{~kg}$ ha. The bitterbrush seed was acquired commercially, but its collection locale was unknown.

Soil in the area $\left(43^{\circ} 37^{\prime} \mathrm{N} 119^{\circ} 24^{\prime} \mathrm{W}\right.$, elevation $1,584 \mathrm{~m}$ ) was a fine, montmorillonitic, frigid Typic Argixeroll. Vegetation prior to the fire included a scattered overstory dominated by western juniper (Juniperus occidentalis Hook.), a shrub layer characterized by mountain big sagebrush (Artemisia tridentata subspp. vaseyana (Rydb.) Beetle) with a minor bitterbrush component, and herbaceous vegetation dominated by bluebunch wheatgrass (Agropyron spicatum (Pursh) Scribn. \& Smith) and bottlebrush squirreltail (Sitanion hystrix (Nutt.) Smith).

In the absence of competing woody vegetation, surviving herbaceous plants and emerging seedlings responded well in the growing seasons following the fire. Bureau of Land Management sampling detected 8,450 bitterbrush seedlings $\mathrm{ha}^{-1}$ in 1991 and $3,410 \mathrm{ha}^{-1}$ in 1992. Crop-year precipitation (September-June), which is highly correlated with annual forage production in the region (Sneva 1982), was 91 and $86 \%$ of the long term mean (255 $\mathrm{mm}, \mathrm{n}=40$ ) for the 1991 and 1992 growing seasons, respectively (NOAA 19901999, Squaw Butte Station, $43^{\circ} 29^{\prime} \mathrm{N}$ $\left.119^{\circ} 43^{\prime} \mathrm{W}\right)$. In accordance with BLM policy, livestock grazing was not allowed in 1991 and 1992 to aid recovery of vegetation, and the charred remains of small trees and shrubs provided the only evidence of the fire after 2 growing seasons.

\section{Pastures and grazing schedules}

Project design was a randomized complete block having 3 replications and 3 treatments with individual pastures $(\mathrm{N}=$ 9) serving as experimental units. Treatments included pastures that were: 1) lightly-grazed by cattle, 2) heavily-grazed by cattle, and 3 ) ungrazed controls. Treatments were not randomized in succeeding years, so findings reflect cumulative effects applied across 3 consecutive growing seasons. Also, treatment designations reflect cattle applications only, even though summering pronghorn (Antilocarpa americana) and wintering deer and elk had free access to all pastures.

Size of grazed pastures ranged from 0.6 to 0.9 ha and ungrazed controls were between 1.4 and 1.6 ha. In 1997 grazed pastures were stocked on 5 May with yearling Hereford $x$ Angus bulls weighing from 317 to $363 \mathrm{~kg}$. Lightly-grazed pastures supported 1 animal, heavily-grazed pastures supported 2 , and grazing continued for 20 days. Given our desire to confine grazing treatments to the boot stage of phenology for the grasses and remove cattle before rapid elongation of bitterbrush twigs, we doubled the initial stocking rates for the next 2 grazing seasons. In 1998 lightly-grazed pastures supported 2 cows and heavily-grazed pastures supported 4 cows with the trial beginning on 21 May and lasting for 12 days. Dry Hereford $x$ Angus cows with a mean weight of $453 \mathrm{~kg}$ $(\mathrm{SE}=26)$ were used. In 1999,18 cows were drawn from a group of dry animals scheduled for culling, and mean weight was slightly heavier $(x=567 \mathrm{~kg}, \mathrm{SE}=14.5$ ). Pastures were stocked on 4 June and grazing continued for 10 days in 1999 . Given the increase in stock numbers between 1997 and 1998, and the use of successively larger animals as the trials progressed, effective stocking rate ( $\left.\mathrm{AU} \mathrm{ha} \mathrm{h}^{-1}\right)$ progressively increased each year.

\section{Shrub and vegetation sampling}

Endpoints of $91-\mathrm{m}$ line transects were marked with metal stakes in each pasture and the position along the tape and distance left or right of the tape recorded for 25 randomly-selected bitterbrush in each pasture. Throughout the trials, any bitterbrush lost to complete defoliation or mortality was replaced with the nearest available neighbor. Prior to each grazing session, the dimensions (greatest diameter and height) of bitterbrush were measured in all pastures, and the ends of any recently defoliated twigs marked with black ink to facilitate detection of subsequent browsing. To index mass of standing crop, all herbage was clipped from ten, $1-\mathrm{m}^{2}$ plots in each pasture just before stocking, oven dried at $40^{\circ} \mathrm{C}$, and subsequently weighed

During grazing trials, we returned every 2 days, relocated each bitterbrush, and tal- 
lied evidence of recent defoliation or trampling. Defoliation signs included twigs displaying a clipped appearance with new yellow wood on the ends or bark skinned from the last few millimeters of the terminal by a cow's biting and pulling motions. Broken stems and twigs or recently displaced bark that revealed bare wood were considered signs of trampling. Stocking was terminated in all pastures when at least $50 \%$ of the herbaceous forage had been utilized or $80+\%$ of the sampled shrubs exhibited some sign of utilization in the heavily-grazed treatment.

After cattle were removed, standing crop was sampled by clipping ten, $1-\mathrm{m}^{2}$ plots per pasture to estimate forage utilization, and the greatest diameter and height of each shrub was recorded to facilitate before and after grazing comparisons of bitterbrush stature. Finally, shrub dimensions were measured a third time in late August to assess spring treatment effects on subsequent summer growth. Again, greatest height and diameter were recorded for each shrub. In addition, length of current season's twig growth was tallied for 2 randomly-selected twigs on each plant.

\section{Statistical procedures}

A repeated measures analysis of variance was used to evaluate treatment $(\mathrm{N}=$ $3)$, year $(\mathrm{N}=3)$, date $(\mathrm{N}=3)$, and 2-way (4 df) and 3-way (8 df) interaction effects on shrub diameter and height. Repeated factors were years and dates within years. Analyses incorporated a first order, autoregressive covariance structure among repeated measures. This is an alternative to adjusting the degrees of freedom for the lack of independence among dates as suggested by Milliken and Johnson (1984). A log transformation helped stabilize variances among treatments, years and dates for diameter measures, but transformation was unnecessary for shrub height. Single degree of freedom contrasts were used for mean separations between treatments on a given date. Within treatments, a paired ttest (2 df) was used to test for changes in shrub dimensions between adjacent dates (Snedecor and Cochran 1967).

For response variables monitored on an annual basis (i.e., measures of standing crop, twig length, levels of forage utilization, and cumulative number of shrubs grazed or trampled), a split-plot analysis of variance was used to evaluate treatment, year, and interaction effects. Treatments ( $2 \mathrm{df})$ served as whole plots, with the block $\mathrm{x}$ treatment interaction (4 df) serving as error term 1. Years were subplots with year ( $2 \mathrm{df})$ and the treatment $x$ year interaction $(4 \mathrm{df})$ tested with the residual error term (12 df). This approach was used because year effects cannot be randomized, and one is forced into an inadvertent split-plot (Cody and Smith 1997). Again, if effects were significant in analyses of variance, single degree of freedom contrasts were used for mean separations

Regression analyses were used to explore and quantify relationships among the number of shrubs grazed or trampled (dependent variables) and several independent variables. Independent variables included expressions quantifying passage of time, forage availability, numbers of cattle, pasture size, and several combinations of these [i.e., days grazed, AU days, area available (ha), forage available ( $\mathrm{kg}$ and $\left.\mathrm{kg} \mathrm{ha}^{-1}\right)$, stocking rates $\left(\mathrm{AU} \mathrm{ha}{ }^{-1}, \mathrm{AU}\right.$ days $\mathrm{ha}^{-1}$ ), and stocking pressure ( $\mathrm{kg}$ forage $\mathrm{AU}^{-1}, \mathrm{~kg}$ forage $\mathrm{ha}^{-1} \mathrm{AU}^{-1}$, and $\mathrm{kg}$ forage $\mathrm{AU}^{-1}$ day $\left.{ }^{-1}\right)$ ]. Scattergrams relating numbers of bitterbrush trampled to passage of time suggested linear models might suffice. Depictions of bitterbrush grazed and passage of time suggested a curvilinear function might be required.

Given a high degree of variability in herbage production among pastures, statistical significance for analyses of standing crop and forage utilization was accepted at $P<0.10$. Statistical significance in all other analyses and for mean separations was accepted at $\mathrm{P}<0.05$. Throughout the manuscript, numbers following a “ \pm " symbol are standard errors (SE) of the mean.

\section{Results}

\section{Precipitation patterns}

Sneva (1982) established that crop-year forage accumulation in the region was most closely correlated with precipitation totals for the previous Sept.-June period. The weather station with the longest continuous record near our study site was on the Northern Great Basin Experimental Range (referenced as the Squaw Butte Experiment Station in N.O.A.A. (2001) documents) some $29 \mathrm{~km}$ southwest and $161 \mathrm{~m}$ lower than our study site. Mean crop-year precipitation $(n=64)$ for the Experimental Range is $26.1 \mathrm{~cm}$, and accumulations for the 1997-1999 crop-years were 132, 196, and 106 percent of average, respectively. Given the disparities in elevation and vegetation between the Experimental Range and our study site, we estimate our research plots receive about
$10 \mathrm{~cm}$ more precipitation annually than the Experimental Range.

\section{Herbaceous standing crop and for- age utilization}

Herbaceous standing crop before grazing averaged $652 \mathrm{~kg} \mathrm{ha}^{-1}$ and varied $(\mathrm{P}=$ $0.05)$ among years but not treatments $(P=$ 0.28). For the 1997-1999 sampling periods, mean herbage production was $777( \pm$ 68), $596( \pm 45)$, and $583( \pm 47) \mathrm{kg} \mathrm{ha}^{-1}$, respectively, in early May. Given a history of light spring use in our grazed pastures, our samples contained a substantial amount of cured material from previous growing seasons for our initial 1997 harvest. Materials were not sorted, however, so we can not quantitatively address live:dead ratios.

Grazing treatment $(P=0.01)$ and year $(P$ $=0.06$ ) effects were significant for levels of forage utilization by cattle, but the treatment $x$ year interaction was not $(P=0.34)$. Mean forage utilization was $32( \pm 7) \%$ in lightly-grazed pastures and $59( \pm 9) \%$ in heavily-grazed units. Across treatments, herbage utilization by cattle averaged $35 \pm$ $7,37 \pm 8$, and $65 \pm 14 \%$ for the $1997-1999$ trials, respectively.

\section{Defoliation and trampling of shrubs by cattle}

The number of bitterbrush browsed by cattle during the trials differed among treatments $(P=0.002)$ and years $(P=$ $0.04)$, but no treatment $x$ year interaction $(P=0.11)$ occurred. When trials ended, an average of $14( \pm 5) \%$ of the bitterbrush were browsed by cattle in the light-grazing treatment, and $62( \pm 9) \%$ were browsed in heavily-grazed pastures $(P=0.05)$. No bitterbrush were defoliated in the ungrazed controls when cattle were on site (data not shown). Cattle did not initially forage on bitterbrush, but began browsing the plants about days 5-6 in the heavily-grazed treatment and about day 8 in the lightly-grazed pastures (Fig.1).

Among regressions relating the cumulative number of shrubs grazed (dependent variable) to the passage of time and various expressions of herbaceous standing crop or stocking pressure, best fit $\left(\mathrm{r}^{2}=\right.$ $0.63, \mathrm{P}<0.001$ ) was obtained with an exponential decay function (Fig. 2) where stocking pressure, expressed as $\mathrm{kg}$ forage $\mathrm{ha}^{-1} \mathrm{AU}^{-1}$ at the close of the trials, served as the independent variable. Approximately half the bitterbrush were browsed by cattle when standing crop was reduced to about $75 \mathrm{~kg} \mathrm{ha}^{-1} \mathrm{AU}^{-1}$. The rate of browsing on bitterbrush also appeared to 

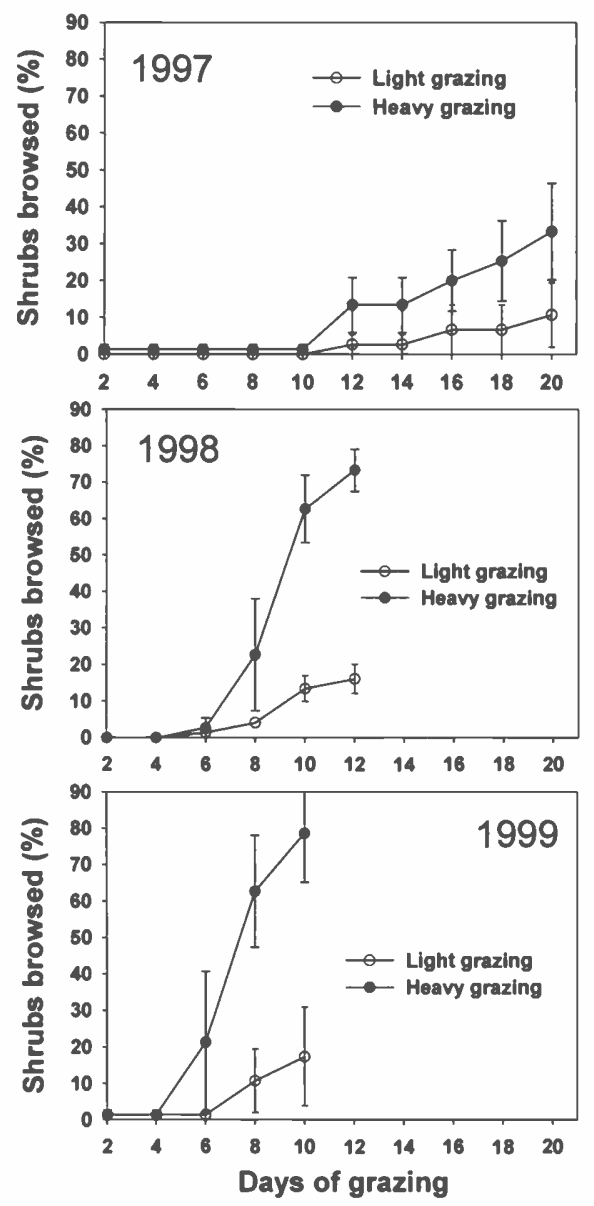

Fig. 1. The percent $( \pm S E, N=3$ ) of bitterbrush browsed by cattle in lightly- and heavily-stocked pastures as grazing trials progressed in the spring of 1997-1999 on big game winter range in southeast Oregon.

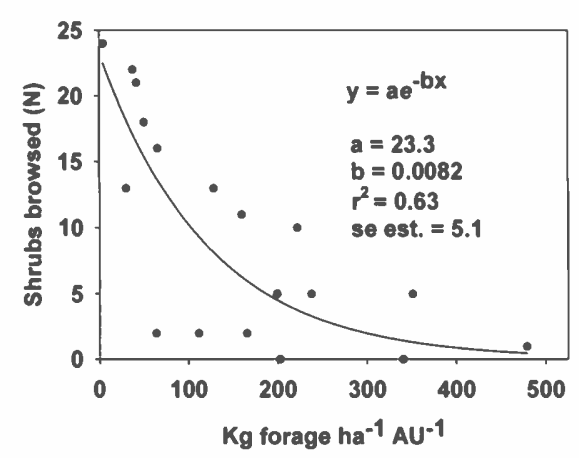

Fig. 2. The relationship between the number of bitterbrush grazed by cattle (out of a total of $\mathbf{2 5}$ monitored shrubs) in lightlyand heavily-stocked pastures in southeast Oregon and $\mathrm{kg}$ forage $\mathrm{ha}^{-1} \mathrm{AU}^{-1}$ during spring stocking periods of 1997-1999. increase when standing crop went below the $75 \mathrm{~kg} \mathrm{ha}^{-1}$ level.

Grazing treatment and year effects were significant $(P<0.01)$ for trampling damage, but treatments responded similarly among years $(P=0.07)$. Across years, 29 $( \pm 4) \%$ of the shrubs were trampled in light-grazing treatments, and $55( \pm 5) \%$ were trampled under heavy-grazing. No trampling effects were noted in control pastures. For individual years across the 2 grazed treatments, percentages of shrubs trampled were $28 \pm 5,49 \pm 7$, and $49 \pm$ 7\%, from 1997-1999, respectively.

Rates of trampling damage to shrubs were well correlated with expressions of stocking rate (AU ha $\left.{ }^{-1}\right)$ ) and time (days). With linear models and cumulative cattle days $\mathrm{ha}^{-1}$ regressed against the number of shrubs trampled, coefficients of determination $\left(r^{2}\right)$ ranged between 0.84 and 0.86 (Fig. 3). Slopes of the regression models differed $(\mathrm{P}<0.01)$ among years and increased slightly as the study advanced from 1997 through 1999. Only 1 shrub, located where the cattle frequently bedded, died from trampling damage.

\section{Canopy diameter and height of bit- terbrush}

With the exception of a grazing treatment $x$ year interaction $(P=0.33)$, all 3 main effects (treatments, years, and sampling dates), 2-way, and 3-way interactions had significant effects $(P<0.05)$ on canopy diameter. When the trials began in 1997 , bitterbrush in grazed treatments were approximately $8 \mathrm{~cm}$ wider $(\mathrm{P}=0.02)$ than bitterbrush in the ungrazed controls (Fig. 4). When cattle were removed from the grazed pastures 20 days later, however, diameters of shrubs were similar across all 3 treatments $(P=0.07)$. Subsequent spring/summer growth of shrubs in the grazed pastures increased diameters by 7 to $8 \mathrm{~cm}$ in 1997 , while shrubs in the ungrazed controls only expanded by about $3 \mathrm{~cm}(\mathrm{P}<0.01)$. In both 1998 and 1999, browsing by cattle in the heavily-grazed pastures reduced $(P<0.01)$ the diameter of bitterbrush such that they were the same width as bitterbrush in the ungrazed controls. Compensatory growth occurred in the heavily-grazed pastures in both 1998 and 1999, however, and bitterbrush were greater in diameter than ungrazed controls $(P<0.01)$ and equal to the lightly-grazed treatment when fall dimensions were recorded. Overwinter browsing by big game reduced $(P=0.05)$ shrub diameters in grazed pastures after fall 1997 measurements (Fig. 4), but big game had no affect on bittrbrush diameter thereafter.
Among analyses of shrub height, all main effects (treatment, years, and dates) were significant $(P<0.03)$ as were the treatment $\mathrm{x}$ date and year $\mathrm{x}$ date interactions $(P<0.01)$. Bitterbrush heights were similar among treatments when the study began (Fig. 5), and unlike shrub diameters, browsing by cattle did not reduce heights of bitterbrush during any of the grazing trials. Fall and overwinter browsing by big game, however, did reduce $(P<0.05)$ the height of bitterbrush in all treatments over the 1997 and 1998 fall/winter periods. Light spring grazing among bitterbrush stimulated summer height growth compared to the other 2 treatments (Fig. 5). Across years, shrubs in the lightly-grazed pastures were more than $4 \mathrm{~cm}$ taller $(\mathrm{P}<$ 0.04 ) at the end of the growing season than cohorts in the heavily-grazed and ungrazed control treatments. With the exception of the heavily grazed pastures in 1999 , shrubs in all treatments were typically taller in the fall than they were just before grazing started in the spring. In 1999 in the heavily grazed pastures, bitterbrush were $37 \mathrm{~cm}$ tall in the spring and only $38 \mathrm{~cm}$ tall $(P=0.6)$ at the end of the growing season. Two factors likely contributed to this lack of growth. First, 1999 was the driest year of the study, and second, we observed the highest levels of forage utilization $(87 \pm 7 \%)$ and browsing on bitterbrush in the heavily grazed treatment during that year.

\section{Current season's twig growth}

Significant treatment $(P=0.03)$ and year $(P<0.01)$ effects occurred for current season's twig growth, but treatment responses were similar across years $(\mathrm{P}=$ $0.28)$. Growth increments reflected annual precipitation patterns, and were similar ( $\mathrm{P}$ $=0.16)$ for the $1997(12.6 \mathrm{~cm})$ and 1999 $(10.5 \mathrm{~cm})$ growing seasons. Current year growth was nearly twice as long $(24.2 \mathrm{~cm}$, $P<0.01$ ), however, in 1998, the wettest of the 3 years sampled. Twig growth in the grazed treatments (lightly-grazed $=16 \mathrm{~cm}$ and heavily-grazed $=16.7 \mathrm{~cm}$ ) was similar $(P=0.20)$, and shrubs in both of the grazed treatments produced longer $(\mathrm{P} \leq$ $0.05)$ twigs than shrubs in the ungrazed pastures $(14.8 \mathrm{~cm})$ each year.

\section{Discussion}

Earlier studies have generally established that livestock progressively consume more bitterbrush as the growing season advances (Lesperance et al. 1970, Stuth and Winward 1977, Neal 1981, 

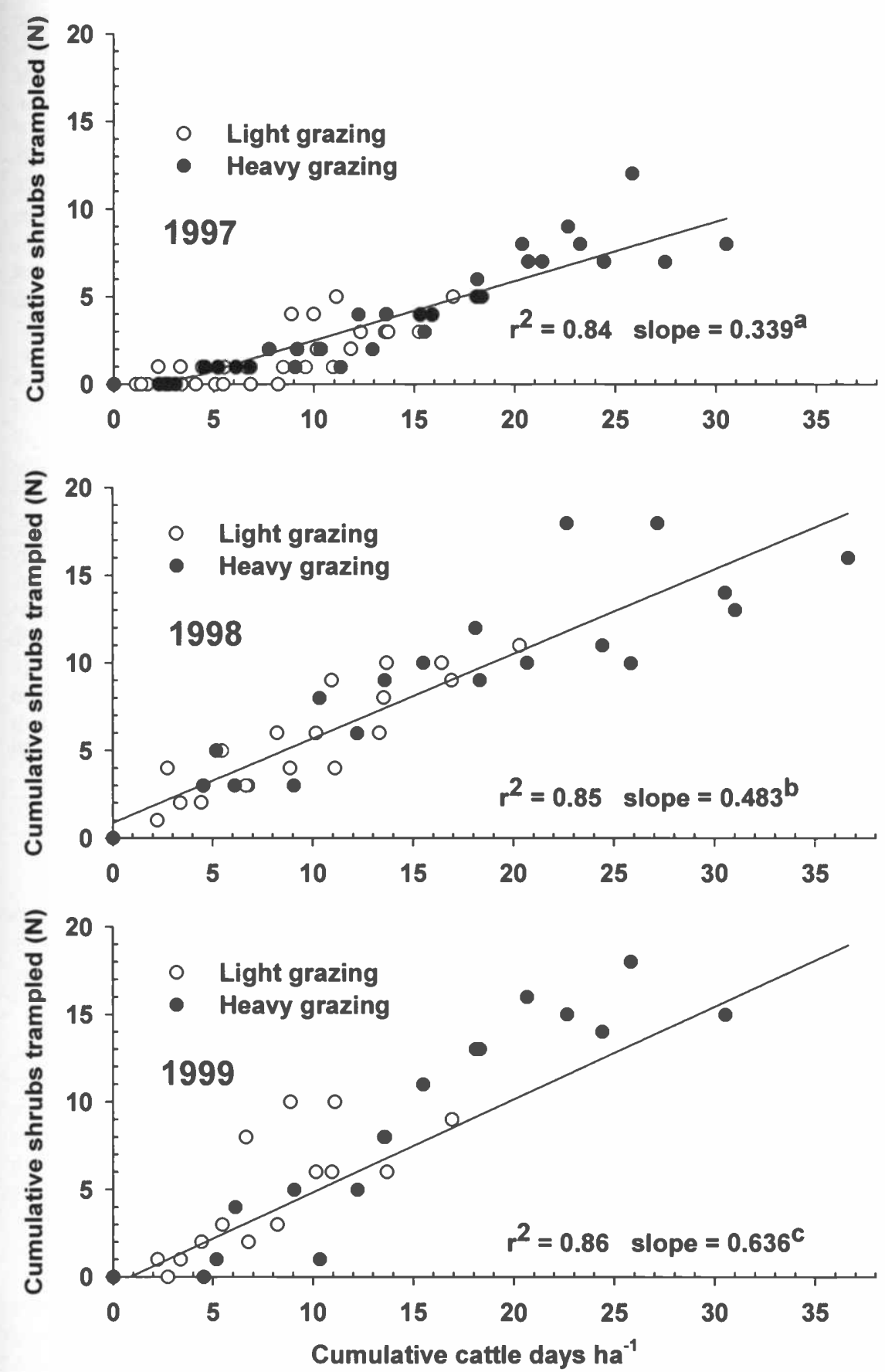

Fig. 3. The cumulative number of bitterbrush trampled by cattle in lightly and heavilystocked pastures monitored at 2-day intervals as grazing trials progressed in the spring of 1997-1999 on big game winter range in southeast Oregon. Slopes of regression lines sharing a common letter are not significantly different $(P>0.05)$.

Urness 1981, and Ganskopp et al. 1999). In our earlier research, about $25 \%$ of the shrubs were browsed by cattle when accompanying grasses were in the vegetative to late-boot growth stage and stocking rates were between 11 to $19 \mathrm{AU}$ days $\mathrm{ha}^{-1}$ (Ganskopp et al. 1999). This study, with stocking rates in the light treatments ranging between 11 and $22 \mathrm{AU}$ days ha ${ }^{-1}(\bar{x}=$ terbrush experienced some degree of browsing (Fig. 1), and mean shrub diameter was reduced by $4 \mathrm{~cm}$ in 1998 and 10 $\mathrm{cm}$ in 1999 (Fig. 4).

Two aspects of our data suggest cattle prefer grazing to browsing within this shrub/grass community early in the growing season. First, in the early days of the trials, cattle in both grazing treatments essentially ignored bitterbrush (Fig. 1). Thereafter (days 6 to 12) they began foraging on bitterbrush. Second, cattle in the heavy grazing treatment started using the bitterbrush about 2 to 6 days sooner than cattle in lightly-grazed pastures. These 2 points suggest forage availability, or possibly forage quality, must decline to some critical threshold before the cattle begin to browse upon bitterbrush. The negative relationship between the total number of shrubs grazed and available herbage at the end of the trials (Fig. 2) lends credence to the first argument and implies that cattle began actively seeking bitterbrush when available herbage declined to 100 tol50 $\mathrm{kg} \mathrm{ha}^{-1} \mathrm{AU}^{-1}$.

Balph and Malechek (1985) investigated trampling of grass tussocks by cattle and noted a disproportionate preference for treading upon interspaces and an avoidance of the most elevated tussocks. Subsequent work also showed that as plant stature decreased, tussocks were more likely to be trampled in short duration grazing programs (Balph et al. 1989). The bitterbrush in this study was relatively uniform in age (7-9 yr) and height (26 to 43 $\mathrm{cm})$. Given those dimensions, they were essentially a component of the herbaceous canopy and were not a serious impediment to livestock travel. Guthery and Bingham (1996) discussed the theoretical aspects of vegetation trampling by cattle and suggested probabilities were simply time/density functions when grazing was nonindependent and nonrandom (i.e., short-duration management). The size of our pastures and our stocking rates assured relatively uniform use of the area. Our data supported the Guthery and Bingham (19.96) hypothesis, as the independent variable of cumulative cattle days ha ${ }^{-1}$ accounted for about $85 \%$ of the variability in the number of shrubs trampled by cattle (Fig. 3).

Lewis (1980) studied simulated browsing and trampling among young conifers and found only the most severe treatments affected seedling height or survival. With light and heavy grazing, we found $28( \pm 4)$ and $55( \pm 5) \%$ of our bitterbrush, respectively, endured some degree of trampling, but few exhibited any deleterious, long 


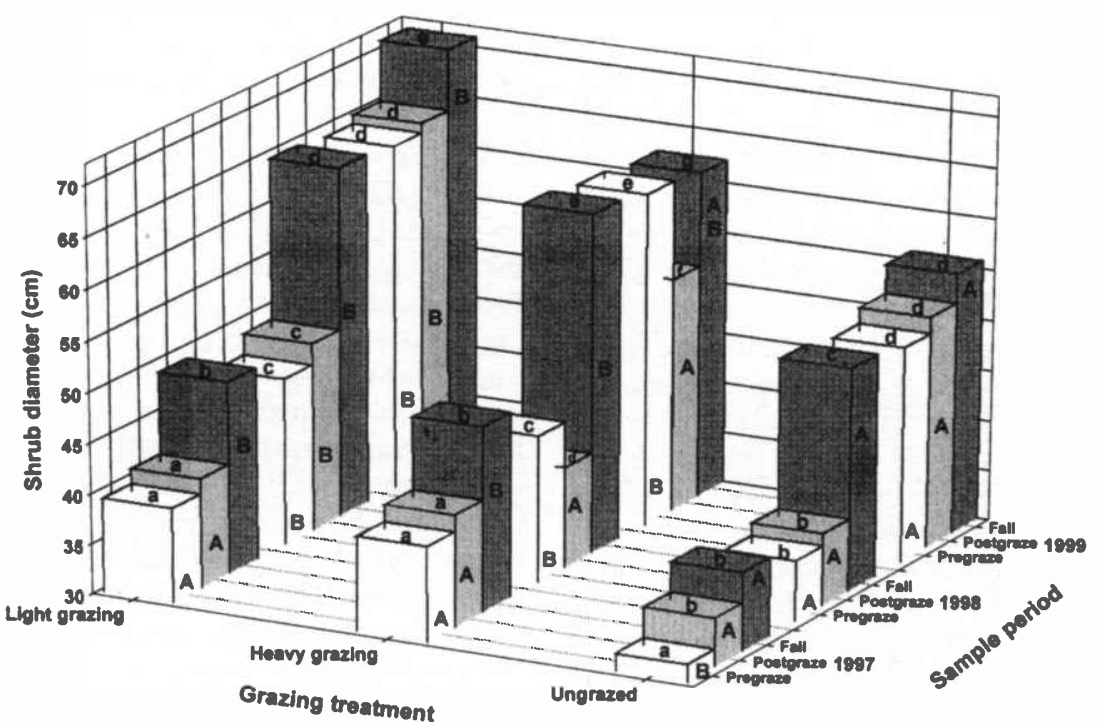

Fig. 4. Canopy diameters of bitterbrush before (pregrazing) and after (postgrazing) cattle turnout and at the end of the growing season (fall) during 1997-1999 on big game winter range in southeast Oregon. Treatment means within a year and sampling period (row) sharing a common upper case letter on the side of a bar are not significantly different $(P>$ 0.05). Means for a given treatment (column) sharing a common lower case letter between adjacent sampling periods are not significantly different $(P>0.05)$.

term effects. In most instances, only 1 or 2 twigs were affected, but some shrubs experienced fractured main stems and persisted for the duration of the study with little evidence of stress. We suspect bitterbrush might escape trampling when its lowest branches originate from sources higher than the surrounding herbaceous layer.

Grazing of herbaceous vegetation among shrubs removes competing leaf area. This is thought to slow the extraction of limited moisture and nutrients from the soil leaving more resources available for the shrubs (Garrison 1953, Hubbard 1957, Ferguson and Basile 1966, McConnel and Smith 1977, Neal 1981, Reiner and Urness 1982). This was probably the mechanism that stimulated shrub growth in our light-grazing treatment, as light cattle grazing had little if any direct effect on bitterbrush dimensions. Bitterbrush responded favorably over the growing season to the partial removal of the herbaceous component and were wider, taller, and supported longer twigs $(P<0.05)$ in the fall than shrubs in the ungrazed controls.

Overwinter and early spring browsing of bitterbrush also stimulates subsequent twig growth (Garrison 1953, McConnel and Smith 1977, Kituku et al. 1994). This response is attributed to 2 mechanisms: 1 ) the absence of apical dominance (Tueller and Tower 1979) and 2) altered resource allocation patterns within the shrubs
(Billbrough and Richards 1993). Both of these modes of action and a release from competition probably came into play in our heavily-grazed pastures.
Much of bitterbrush's positive response to spring cattle grazing is likely related to its seasonal patterns of growth. With the first warming temperatures in spring, bitterbrush initiates flowering, and little if any twig elongation occurs. As bitterbrush flowers, competing grasses like bluebunch wheatgrass and Idaho fescue (Festuca idahoensis Elmer) pass through vegetative stages of growth and into the boot stage of development. Grazing of the grasses at this time removes both transpiring leaves and apical meristems and retards subsequent root growth and herbage development (Ganskopp 1988). This lets bitterbrush exploit resources that might typically be taken up by grasses at the exact time that twigs are starting to grow.

In practice, bitterbrush responses to grazing treatments may vary substantially from year to year and across its range. Kindschy (1982) noted that up to 40 percent of the annual variation in twig growth of bitterbrush can be explained by cropyear precipitation dynamics. Garrison (1953) also advised that managers might not see shrub responses to grazing on arid sites or during dry years when all components of the plant community are affected by limited soil moisture supplies.

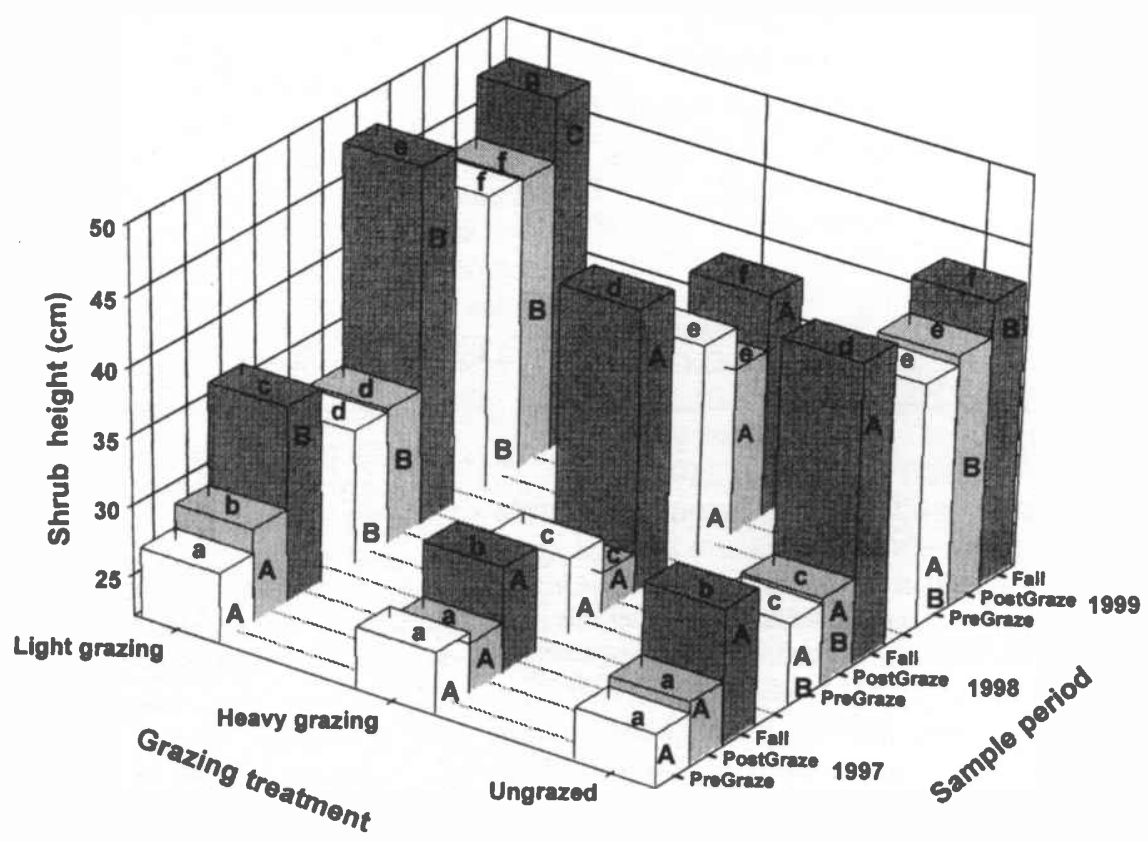

Fig. 5. Canopy height of bitterbrush before (pregrazing) and after (postgrazing) cattle turnout and at the end of the growing season (fall) during 1997-1999 on big game winter range in southeast Oregon. Treatment means within a year and sampling period (row) sharing a common upper case letter on the side of a bar are not significantly different $(P>$ 0.05). Means for a given treatment (column) sharing a common lower case letter between adjacent sampling periods are not significantly different $(P>0.05)$. 
To stimulate bitterbrush growth in grass/shrub communities we suggest the stand be lightly-grazed (about 30 to 40 percent utilization of the herbaceous component) by cattle when bitterbrush is flowering and accompanying grasses are in the vegetative to late-boot stages of phenology. Bitterbrush in lightly-grazed stands exhibited about a 50 percent greater increase in diameter, 30 percent greater increase in height, and about 8 percent longer twigs than cohorts in ungrazed pastures. On a conservative note, most coolseason grasses are sensitive to and easily harmed by overgrazing at this time of year (Ganskopp 1988). Because most managers want to sustain both the herbaceous and woody components of their pastures, grazing to stimulate bitterbrush growth should probably be applied in a deferred rotation program to assure an overall healthy plant community.

Heavier grazing applications, with utilization levels approaching 60 percent of the herbaceous component, can have immediate impact on bitterbrush stature. Compensatory growth occurred, however, and shrubs in heavily-grazed pastures exhibited about a 30 percent greater diameter increment at the end of the growing season and about 13 percent longer twigs than bitterbrush in ungrazed units for 2 out of 3 years. At the end of the growing season in the third year of our study, however, shrubs in the heavily-grazed pastures were not as tall as cohorts in ungrazed areas. That year was the driest of the 3 sampled, herbage and browse incurred their highest rates of utilization, and those 2 factors probably combined to reduce the length of the effective growing season and ability of bitterbrush to recover.

Cattle in the sagebrush/steppe typically use herbaceous forages in the spring months (Vavra and Sneva 1978) and avoid bittertbrush until the grasses begin flowering (Ganskopp et al. 1999). Measures of residual standing crop among our grazing treatments suggested cattle began foraging on bitterbrush in the spring months when standing crop declined to 100 to $150 \mathrm{~kg} \mathrm{ha}^{-1}$. In our environment, that occurred at about a 60 percent utilization level, by which time the cattle had essentially grazed and then regrazed all available herbage. We do not recommend this degree of forage utilization, but should it occur, bitterbrush can respond by generating as much growth as shrubs in ungrazed pastures if cattle are removed while there is still sufficient soil moisture for twig growth.
Ayers, D.M., D.J. Bedunah, and M.G. Harrington. 1999. Antelope bitterbrush and Scouler's willow response to a shelterwood harvest and prescribed burn in western Montana. W. J. Appl. For. 14:137-143.

Balph, D.F. and Malechek, J.C. 1985. Cattle trampling of crested wheatgrass under shortduration grazing. J. Range Manage. 38:226-227.

Balph, D.F., M.H. Balph, and J.C. Malechek. 1989. Cues cattle use to avoid stepping on crested wheatgrass tussocks. J. Range Manage. 42:376-377.

Billbrough, C.J. and J.H. Richards. 1993. Growth of sagebrush and bitterbrush following simulated winter browsing: mechanisms of tolerance. Ecol. 74:481-492.

Billings, W.D. 1952. The environmental complex in relation to plant growth and distribution. Quart. Rev. Biol. 27:251-265.

Clark, R.G., C.M. Britton, and F.A. Sneva. 1982. Mortality of bitterbrush after burning and clipping in eastern Oregon. J. Range Manage. 35:711-714.

Clements, C.D. and J.A. Young. 2001. Antelope bitterbrush seed production and stand age. J. Range Manage. 54:269-273.

Cody, R.P. and J.K. Smith. 1997. Applied statistics and the SAS programming language. Prentice Hall, N.J.

Cronquist, A., N.H. Holmgren, and P.K Holmgren. 1997. Intermountain flora: vascular plants of the intermountain west, USA, vol. 3. New York Botanical Garden, New York.

Dealy, J.E. 1970. Survival and growth of bitterbrush on the Silver Lake deer winter range in central Oregon. USDA For. Serv. Res. Note PNW-133, PNW Forest and Range Exp. Sta., Portland, Ore.

Ferguson, R.B. 1968. Survival and growth of young bitterbrush browsed by deer. J. Wildl. Manage. 32:769-772.

Ferguson, R.B. and J.V. Basile. 1966. Topping stimulates bitterbrush growth. J. Wildl. Manage. 30:839-841.

Ganskopp, D. 1988. Defoliation of Thurber needlegrass: herbage and root responses. J. Range Manage. 41:472-476.

Ganskopp, D. and D. Bohnert. 2001. Nutritional dynamics of 7 northern Great Basin grasses. J. Range Manage. 54:640-647.

Ganskopp, D, T. Svejcar, F. Taylor, J. Farstvedt, and K. Paintner. 1999. Seasonal cattle management in 3 to 5 year old bitterbrush stands. J. Range Manage. 52:166-173.

Garrison, G.A. 1953. Annual fluctuation in production of some eastern Oregon and Washington shrubs. J. Range Manage. 6:117-121.

Guthery, F.S. and R.L. Bingham. 1996. A theoretical basis for study and management of trampling by cattle. J. Range Manage. 49:264-269.

Hickman, O.E. 1975. Seasonal trends in the nutritive content of important range forage species near Silver Lake, Oregon. USDA For. Serv. Res. Paper PNW-187, PNW Forest and Range Exp. Sta., Portland, Ore.

Hormay, A.L. 1943. Bitterbrush in California. US For. Serv. Calif. For. and Range Exp Sta.,. Res. Note-34, Berkeley, Calif.

Hubbard, R.L. 1957. The effects of plant competition on the growth and survival of bitterbrush seedlings. J. Range Manage. 10:135-137.

Hubbard, R.L. 1964. A guide to bitterbrush seeding in California. USDA For. Serv. PSW Exp. Sta., Berkeley, and Calif. Dept. Fish and Game Resour.

Jensen, C.H. and P.J. Urness. 1979. Winter cold damage to bitterbrush related to spring sheep grazing. J. Range. Manage. 32:214-216.

Kindschy, R.R. 1982. Effects of precipitation variance on annual growth of 14 species of browse shrubs in southeastern Oregon. J. Range Manage. 35:265-266.

Kinuthia, R.N., J. Powell, F.C. Hinds, and R.A. Olson. 1992. Range animal diet composition in southcentral Wyoming. J. Range Manage. 45:542-545.

Kituku, V.M., J. Powell, and R.A. Olson. 1994. Sites, mowing, 2,4-D, and seasons affect bitterbrush twig morphology. J. Range Manage. 47:200-205.

Kituku, V.M., W.A. Laycock, J. Powell, and A.A. Beetle. 1995. Propagating bitterbrush twigs for restoring shrublands, p. 327-328. In: B.A. Roundy, E.D. McArthur, J.S. Haley, and D.K Mann (comps.), Proc. wildland shrub and arid land restoration symposium. USDA-For. Serv., Intermountain Res. Sta., Gen. Tech. Report INT-GTR-315. Ogden, Ut.

Kituku, V.M., J. Powell, M.A. Smith, and R.A. Olson. 1992. Increasing bitterbrush nutrient quality with 2,4-D, mowing, and burning in south central Wyoming. J. Range Manage. 488-493.

Kufeld, R.C., O.C. Wallmo, and C. Feddema. 1973. Foods of the Rocky Mountain mule deer. USDA For. Serv. Res. Paper RM-111, Fort Collins, Colo.

Lesperance, A.L., T.T. Tueller, and V.R. Bohman. 1970. Competitive use of the range forage resource. J. Anim. Sci. 30:115-121.

Lewis, C.E. 1980. Simulated cattle injury to planted slash pine: combinations of defoliation, browsing and trampling. J. Range Manage. 35:340-345.

McConnel, B.R. and J.G. Smith. 1977. Influence of grazing on age-yield interactions in bitterbrush. J. Range Manage. 20:91-93.

Milliken, G.A. and Johnson, D.E. 1992. Analysis of messy data: designed experiments. Chapman and Hall, New York.

Mueggler, W.R. and J.P. Blaisdell. 1958. Effects on associated species of burning, rotobeating, spraying and railing sagebrush. J. Range Manage. 11:61-66.

National Oceanic and Atmospheric Administration (NOAA). 1990-2001. Climatological data annual summary, Oregon. 95-106:(13) 
Neal, D.L. 1981. Improvement of Great Basin deer winter range with livestock grazing, $\mathrm{p}$. 61-73. In: Proc. Wildlife-livestock relationships symposium. Forest, Wildlife \& Range Exper. Sta., Univ. Idaho, Moscow, Ida.

Reiner, R.J. and P.J. Urness. 1982. Effect of grazing horses managed as manipulators of big game winter range. J. Range. Manage. 35:567-571.

Snedecor, G.W. and W.C. Cochran. 1967. Statistical methods. lowa State Univ. Press. Ames, lowa.

Sneva, F.A. 1982. Relation of precipitation and temperature with yield of herbaceous plants in eastern Oregon. Int. J. Biometeor. 26:263-276.
Stuth, J.W. and A.H. Winward. 1977. Livestock-deer relations in the lodgepole pine-pumice region of central Oregon. J Range Manage. 30:110-116.

Tueller, P.T. and J.D. Tower. 1979. Vegetation stagnation in three-phase big game exclosures. J. Range Manage. 32:258-263.

Urness, P.J. 1981. Livestock as tools for managing big game winter range in the intermountain west, p. 20-31. In: Proc. Wildlifelivestock relationships symposium. Forest, Wildlife \& Range Exp. Sta., Univ. of Idaho, Moscow, Ida.
Vavra, M. and F. Sneva. 1978. Seasonal diets of five ungulates grazing the cold desert biome. In: D.N. Hyder (ed.), Proc. $1^{\text {st }}$ Int. Rangeland Congress Soc. Range Manage. Denver, Colo.

Winward, A.H. and J. Alderfer-Findley. 1983. Taxonomic variations of bitterbrush (Purshia tridentata) in Oregon, p. 25-30. In: Tiedemann, A.R. and K.L. Johnson (comps.) Proc. Research and management of bitterbrush and cliffrose in western North America. USDA-For. Serv., Intermountain Forest and Range Exp. Sta. Gen. Tech. Rep. INT-152. Ogden, Ut. 